\title{
Screening and Chemical Management of Mungbean against Mungbean Yellow Mosaic Virus in Jammu Region
}

\author{
Ranbir Singh, Dechan Choskit*, Stanzin Diskit and Manpreet Kaur
}

Division of Plant Pathology, FoA, Main Campus, Chatha, SKUAST-Jammu, India

*Corresponding author

\section{A B S T R A C T}

\begin{tabular}{|l|}
\hline Ke y w o r d s \\
$\begin{array}{l}\text { Mungbean mosaic } \\
\text { virus, Disease } \\
\text { incidence, Disease } \\
\text { severity, Screening } \\
\text { and Chemical } \\
\text { management }\end{array}$ \\
\hline Article Info \\
\hline $\begin{array}{l}\text { Accepted: } \\
\text { 04 December } 2020 \\
\text { Available Online: } \\
\text { 10 January } 2021\end{array}$ \\
\hline \hline
\end{tabular}

\begin{abstract}
Mungbean yellow mosaic is the most destructive disease widely prevalent in summer and rainy season and a major constraint to the cultivation of legumes in India. Screening of mungbean germplasm was done at research farm of SKUAST Jammu and the study showed that out of ten germplasm SML-668, ML-613, ML-5, PS-16, ML-818 were moderately resistant whereas PAU-911 and PDM-116 were moderately susceptible and T9, T-44 and K-851 were susceptible. Also, different insecticides (arbofuran 3G, imadacloprid 17.8 SL, metasystox $25 \mathrm{EC}$, thiomethoxam $25 \mathrm{WG}$ and profenofos $50 \mathrm{EC}$ ) were evaluated against mungbean yellow mosaic virus under field condition and the result revealed that at 60 DAS, imidacloprid (seed treatment) + carbofuran (soil application)+ imidacloprid (Foliar spray) showed the lowest disease intensity $(7.33 \%)$ followed by thiomethoxam (seed treatment) + carbofuran (soil application) + profenofos (Foliar spray) (10.00\%), imidacloprid (Foliar spray) (10.66\%), imidacloprid (seed treatment) $(11.33 \%)$, thiomethoxam (seed treatment) (12\%), metasystox (Foliar spray) (12.33\%), profenofos (Foliar spray) (14.00\%), imidacloprid (seed treatment) + carbofuran (soil application) + metasystox (Foliar spray) (14.33\%) and carbofuran (soil application) (15.33\%).
\end{abstract}

\section{Introduction}

Green gram commonly known as Mungbean or Mung (Vigna radiata L.) is one of the thirteen food legumes grown in India and third most important pulse crop after chick pea and pigeon pea. It is an important short duration summer food legume in the tropical and sub tropical countries of the world. In India the total area sown under mungbean is around 4.26 million ha, with a production of 2.01 million tons and productivity of 472 $\mathrm{kg} / \mathrm{ha}$ (Anonymous,, 2018). In Jammu and
Kashmir, mungbean is grown over an area of 1.4 thousand ha with an annual production of 0.8 thousand tons and average yield of $587 \mathrm{~kg} / \mathrm{ha}$ (Anonymous, 2015). Mungbean is prone to several fungal, bacterial and viral diseases. Among all the viruses, mungbean yellow mosaic virus (MYMV) is the most destructive.

The virus is not seed or soil borne or sap transmissible (Nene, 1973) but only by its vector whitefly B.tabaci (Hemiptera: Aleyrodidae), which causes severe damage to 
crops by feeding on sap, secreting honey dew and transmitting virus diseases (Jose and Usha, 2003). In India the virus was first reported from fields of IARI, New Delhi in 1960. MYMV belongs to the genus Begomovirus of the family Geminivirideae (Bos, 1999). The virus has geminated particle $(20 \times 30 \mathrm{~nm})$ and the coat protein encapsulates circular, single stranded DNA genome of approximately $2.8 \mathrm{~kb}$. MYMV causes irregular green and yellow patches in older leaves and complete yellowing of younger leaves. The disease can reduce mungbean yield upto 100 per cent or even kill a plant (Kitsanachandee et al., 2013). Thus keeping in view the importance of the disease and losses caused, studies on screening and chemical management of mungbean against yellow mosaic disease was done at research farm of SKUAST- Jammu under field condition.

\section{Materials and Methods}

\section{Screening of mungbean germplasm}

Ten germplasm of mungbean viz. ML-5, PAU-911, T-44, K-851, ML-613, PS-16, PDM-116, ML-818, SML-668 and T-9 were collected from various sources and grown under natural epiphytotic conditions for determining resistance against MYMV and no plant protection measures were adopted. Observation on disease incidence and severity were recorded at 15 days interval. Severity of the disease was determined by using 0-5 scale (As per modified scale of Bashir et al., 2005) (Table 1).

\section{Scoring}

The percentage of disease incidence and percentage of disease index (PDI) were calculated by using the standard formula (McKinney, 1923):

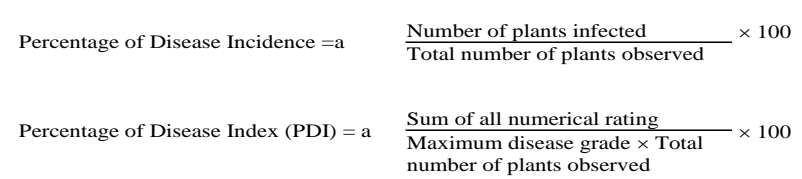

\section{Evaluation of insecticides against Mungbean Yellow Mosaic Virus (MYMV) under field conditions:}

The experiment was laid out using susceptible variety of mungbean (T9) in Randomised Block Design with nine treatments and three replications including untreated control. The different insecticides used for the experiment were carbofuran $3 \mathrm{G}$, imadacloprid 17.8 SL, metasystox $25 \mathrm{EC}$, thiomethoxam $25 \mathrm{WG}$ and profenofos $50 \mathrm{EC}$.

The first spray of insecticide was given at the appearance of the disease symptoms followed by two sprays at 15 days interval. In case of control only water was sprayed. Per cent Diseases intensity of MYMV in treated and untreated plots was calculated by using $0-5$ scale (As per modified scale of Bashir et al., 2005) (Table 1).

\section{Results and Discussion}

Ten mungbean germplasm were screened for resistance against mungbean yellow mosaic virus (MYMV) under field conditions. The results showed that at 60 DAS the disease incidence ranged from 60.00-96.67\% (Table 2 ) while the per cent disease severity ranged from $14.33-42.33 \%$ (Table 3). Further the study revealed that no germplasm was immune to the disease, however, SML-668, ML-613, ML-5, PS-16, ML-818, were found moderately resistant, PAU-911 and PDM-116 showed moderately susceptible, while T-9, T44 and K-851 showed susceptible (Table 3) against the disease. Similar type of varietal evaluations were also documented previously by several workers (Chenulu et al., 1979; Singh, 1980; Singh et al., 1996; Marappa et 
al., 2003; Ganapathy, 2003 and Peerajade et al., 2004).

The evaluation of different insecticides for the management of MYMV was done under field conditions and the results revealed that all the chemicals were effective in reducing the spread of the disease by controlling the population of whiteflies which are the main vector of the virus except control plots. At 60 DAS, imidacloprid (seed treatment) + carbofuran (soil application) + imidacloprid (foliar spray) $(7.33 \%)$ was found stastically superior to other treatments followed by thiomethoxam (seed treatment) + carbofuran (soil application) + profenofos (foliar spray) $(10.00 \%)$, imidacloprid (foliar spray) (10.66\%), imidacloprid (seed treatment) $(11.33 \%)$, thiomethoxam (seed treatment) (12\%), metasystox (foliar spray) (12.33\%), profenofos (foliar spray) (14.00\%), imidacloprid (seed treatment) + carbofuran (soil application)+ metasystox (foliar spray) $(14.33 \%)$ and carbofuran (soil application) $(15.33 \%)$ (Table 4).

Table.1 Scale used to measure intensity of mungbean yellow mosaic virus

\begin{tabular}{|c|c|c|}
\hline Disease Severity & Per cent Infection & Reaction Group \\
\hline $\mathbf{0}$ & No symptom & Highly Resistant \\
\hline $\mathbf{1}$ & Up to $10 \%$ Infection & Resistant \\
\hline $\mathbf{2}$ & More than $10 \%$ to $20 \%$ Infection & Moderately Resistant \\
\hline $\mathbf{3}$ & More than $20 \%$ to $30 \%$ Infection & Moderately Susceptible \\
\hline $\mathbf{4}$ & More than 30 to $50 \%$ Infection & Susceptible \\
\hline $\mathbf{5}$ & More than $50 \%$ Infection & Highly Susceptible \\
\hline
\end{tabular}

Table.2 Incidence of mungbean yellow mosaic virus (MYMV) on different germplasm at different dates after sowing (DAS) under field conditions

\begin{tabular}{|c|c|c|c|}
\hline \multirow{2}{*}{ Germplasm } & \multicolumn{3}{|c|}{ Disease Incidence (\%) } \\
\hline & 30 DAS & 45DAS & 60DAS \\
\hline ML-818 & 56.67 & 56.67 & 60.00 \\
\hline SML-668 & 53.33 & 56.67 & 66.67 \\
\hline ML-613 & 50.00 & 53.33 & 66.67 \\
\hline PAU-911 & 60.00 & 70.00 & 86.67 \\
\hline T-9 & 76.67 & 83.33 & 93.33 \\
\hline ML-5 & 56.67 & 66.67 & 76.67 \\
\hline PS-16 & 50.00 & 66.67 & 70.00 \\
\hline T-44 & 73.33 & 83.33 & 96.67 \\
\hline K-851 & 70.00 & 83.33 & 96.67 \\
\hline PDM-116 & 66.67 & 70.00 & 80.00 \\
\hline
\end{tabular}


Table.3 Intensity of mungbean yellow mosaic virus (MYMV) on different germplasm at different dates after sowing (DAS) under field conditions

\begin{tabular}{|c|c|c|c|c|}
\hline \multirow{2}{*}{ Germplasm } & \multicolumn{3}{|c|}{ Disease Incidence (\%) } & \multirow{2}{*}{ Grade } \\
\cline { 2 - 4 } & 30DAS & 45DAS & 60DAS & MR \\
\hline ML-818 & 11.33 & 14.33 & 16.33 & MR \\
\hline SML-668 & 12.60 & 14.66 & 16.00 & MS \\
\hline ML-613 & 22.67 & 25.33 & 27.00 & S \\
\hline PAU-911 & 31.33 & 39.33 & 42.33 & MR \\
\hline T-9 & 12.00 & 16.33 & 18.00 & MR \\
\hline ML-5 & 12.33 & 14.33 & 16.00 & S \\
\hline PS-16 & 30.33 & 32.33 & 42.00 & MS \\
\hline T-44 & 30.33 & 32.33 & 42.00 & MR \\
\hline K-851 & 21.44 & 24.67 & 26.33 & 14.33 \\
\hline
\end{tabular}

Table.4 Evaluation of different insecticides against mungbean yellow mosaic virus (MYMV) under field conditions on variety (T-9)

\begin{tabular}{|l|c|c|c|}
\hline \multicolumn{1}{|c|}{ Treatment } & \multicolumn{3}{|c|}{ Disease Intensity (\%) } \\
\cline { 2 - 4 } & $\mathbf{3 0}$ DAS & $\mathbf{4 5}$ DAS & $\mathbf{6 0}$ DAS \\
\hline Soil application of Carbofuran 3G & 13.33 & 14.00 & 15.33 \\
& $(21.66)$ & $(21.93)$ & $(22.88)$ \\
\hline Seed treatment with Imadacloprid 17.8 SL & 6.00 & 8.33 & 11.33 \\
& $(14.17)$ & $(17.09)$ & $(19.34)$ \\
\hline Foliar application of Metasystox 25 EC & 6.66 & 9.66 & 12.33 \\
& $(14.92)$ & $(17.75)$ & $(20.65)$ \\
\hline Foliar application of Profenofos 50 EC & 7.00 & 12.33 & 14.00 \\
& $(15.17)$ & $(20.65)$ & $(21.93)$ \\
\hline Foliar application of Imidacloprid 17.8 SL & 5.66 & 8.00 & 10.66 \\
& $(13.72)$ & $(16.69)$ & $(18.69)$ \\
\hline Seed treatment with Thiomethoxam 25WG & 6.33 & 8.66 & 12.00 \\
\hline Seed treatment with Imidacloprid 17.8 SL + soil application & $(14.67)$ & $(17.09)$ & $(19.64)$ \\
\hline of Carbofuran 3G+Foliar spray of Imidacloprid 17.8 SL & 2.66 & 4.66 & 7.33 \\
\hline $\begin{array}{l}\text { Seed treatment with Imidacloprid 17.8 SL + Soil application } \\
\text { of Carbofuran 3G+ Foliar spray of Metasystox 25EC }\end{array}$ & $(9.26)$ & $(12.41)$ & $(15.67)$ \\
\hline $\begin{array}{l}\text { Seed treatment with Thiomethoxam 25WG+ Soil application } \\
\text { of Carbofuran 3G+Foliar spray of profenofos 50EC }\end{array}$ & $(15.67)$ & $(17.27)$ & $(22.24)$ \\
\hline Control & 4.33 & 6.00 & 10.00 \\
\hline SE & $(12.20)$ & $(14.14)$ & $(18.37)$ \\
\hline CD(P=0.05) & 25.33 & 28.00 & 33.33 \\
\hline
\end{tabular}

Based on the results, it is clear that the application of insecticides like imidacloprid, profenofos, thiomethoxam and metasystox in combination with carbofuran were effective in 
minimizing the disease severity in the field. Effectiveness of imidacloprid for the management of whiteflies which is the main vector of the disease was earlier reported by Mote et al., (1993), Walunj and Mote (1995) and Dandale et al., (2001). The effectiveness of the insecticides was attributed to a great extent due to high level of protection, quick knockdown effect on viruliferous vectors and delaying disease appearance as reported by Baranwal and Ahmed (1997) or becoming toxic to vectors before inoculating virus as reported by Somasekara et al., (1997).

\section{References}

Anonymous. 2018. Pulses revolution from food to nutritional security. Crops Division Government of India Ministry of Agriculture \& Farmers Welfare Department of Agriculture, Cooperation \& Farmers Welfare Krishi Bhavan, New Delhi.

Anonymous. 2015. Annual report on average and production of pulses in Jammu Division for the year 2014-2015. Directorate of Agriculture, Jammu.

Baranwal, V.K. and Ahmed, N. 1997, Effect of Clerodendrum aculeatum leaf extract on tomato leaf curl virus. Indian Phytopathology, 50(2): 297-299.

Bashir, M. 2005. Studies on viral diseases of major pulse crops and identification of resistant sources. Technical annual Report of ALP Project. Crop Sciences Institute, National Agricultural Research Center, Islamabad. Pp169.

Bos, L. 1999. Plant viruses: Unique and Intriguing pathogens: Text Book of Plant Virology. Backhuys Publishers. The Netherlands. Pp 305-306.

Chenulu, V.V., Venkateswarlu, V. and Rangaraju, R. 1979. Studies on yellow mosaic diseases of mungbean. Indian Phytopathology, 32: 230-235.

Dandale, H.G., Thakare, A.Y., Tikar, S.N.,
Rao, N.G.V. and Nimbalkar, S.A. 2001. Effect of seed treatment on sucking pests of cotton and yield of seed cotton. Pestology, 25(3): 20.23.

Ganapathy, T. 2003. Annual Meeting and Symposium on Recent Developments in the diagnosis and Management of Plant Diseases for meeting Global Challenges. University of Agricultural Sciences. Pp: 30.

Josh, J. and Usha, R. 2003. Bhendi yellow vein mosaic disease in India is caused by association of a DNA beta satellite with a Begomovirus. Virology, 305: 310-317.

Kitsanachandee, R., Somta, P., Chatchawankanphanich, O., Akhtar, K. P., Shah, T. M., Nair, R., Bains, M., Sirari, T.S., Kaur, A. and Srinives, P. 2013. Detection of quantitative trait loci for mungbean yellow mosaic India virus (MYMIV) resistance in mungbean (Vigna radiata L.) Wilczek) in India and Pakistan. Breeding Science, 63: 367373.

Marappa, N., Savithramma, D.L., Nagaraju, Prameela, H.A. and Krishnamurthy, R.A. 2003. Evaluation of mungbean genotypes against powdery mildew, yellow mosaic virus and bacterial blight diseases. Annual Meeting and Symposium on Recent Developments in the Diagnosis and Management of Plant Diseases for Meeting Global Challenges. University of Agricultural Sciences, Dharwad, pp-31.

McKinney, H.H. 1923. A new system of grading plant diseases. J. Agri. Res., 26: 195-218

Mote, U.N., Datkhile, R.V. and Pawar, S.A. 1993. A new insecticide, imidacloprid, as a seed dresser for the control of sucking pest of cotton. Pestology, 18(2): 5-9.

Nene, Y.L. 1973. Viral diseases of some warm weather pulse crops in India. 
Plant Disease Report, 57:463-467.

Peerajade, D.A., Ravikumar, R.L. and Rao, M.S.L. 2004. Screening of local mungbean collections for powdery mildew and yellow mosaic virus resistance. Indian Journal of Pulses Research, 17(2): 190-191.

Singh, R.N. 1980. Natural infection of bean by mungbean yellow mosaic virus. Indian Journal of Mycology and Plant Pathology, 9(1): 124-126.

Singh, K., Singh, S. and Kumar, R.K. 1996. Inheritance to mungbean yellow mosaic in mungbean. Indian journal of Pulses
Research, 9: 90.

Somasekara, Y.M., Nateshan, H.M. and Muniyappa, V. 1997. Evaluation of neem products and insecticides against whitefly (Bemisia tabaci), a vector of tomato leaf curl geminivirus disease. Indian Journal of Plant Protection, 25(1): 56-59.

Walunj, A.R. and Mote, U.N. 1995. Evaluation of imidacloprid against thrips and whitefly on tomato. Pestology, 19(11): 21-23.

\section{How to cite this article:}

Ranbir Singh, Dechan Choskit, Stanzin Diskit and Manpreet Kaur. 2021. Screening and Chemical Management of Mungbean against Mungbean Yellow Mosaic Virus in Jammu Region. Int.J.Curr.Microbiol.App.Sci. 10(01): 1-6. doi: https://doi.org/10.20546/ijcmas.2021.1001.001 